\title{
The Effectivity of Enterotoxigenic Escherichia coli (Multivalen) Vaccination in Swine Case Study in Bali
}

\author{
Anastasia Sischa Jati Utami*, Ida Ayu Parwati and I Nyoman Suyasa
}

\author{
Assessment Institute for Agricultural Technology (AIAT) Bali, Denpasar-Bali, Indonesia \\ *Corresponding author email: siskajati@gmail.com
}

\begin{abstract}
Swine cattle have high economic advantages and social values in Balinese society. This study aimed to determine the effectiveness of Enterotoxigenic Escherichia coli (ETEC) vaccine in gestating sows. We used 26 gestating sows aged 1.5 years old at their last trimester assigning 13 sows in the control group and 13 sows in treatment group to receive multivalent ETEC vaccine twice: on the 70-75 days of gestation and a booster on 100-105 days of gestation. Sows with the vaccine treatment divided into 3 group that groups $A$ was treated antifimbrial K41, groups B was antifimbrial 987P, while in group C was Antiimbrial K88. The changes in temperature were observed from one day before to 4 days after vaccination in a randomized block design. To determine the antibody formed, blood samples were taken one and two weeks after the first vaccine and five weeks after the booster. The blood sample was analyzed by the Enzyme Linked Immunosorbent Assay (ELISA) technique. The rates of diarrhea and postnatal mortality were also observed. The results showed that the antibody titer level increased significantly in the fifth week in groups A with titer 1,94 $\pm 0,22$ and B with titer $1,98 \pm 0,30$, while the number of diarrhea incidents was $0.9 \%$ compared to control $34 \%$ with a mortality rate of $0 \%$. In conclusion, this multivalent ETEC vaccine is safe to use and has been shown to be effective for ETEC cases in swine.
\end{abstract}

Keywords: ETEC multivalen, vaccination, booster, antibody respon, mortality rate

\begin{abstract}
Abstrak. Ternak babi mempunyai keunggulan ekonomi tinggi dan nilai sosial yang ada di masyarakat Bali. Sapi babi memiliki keunggulan ekonomi dan nilai sosial yang tinggi yang ada pada masyarakat Bali. Penelitian ini bertujuan untuk mengetahui efektivitas vaksin Enterotoksigenik Escherichia coli (ETEC) pada babi bunting. Penelitian dilakukan pada 26 ekor induk babi umur 1,5 tahun pada babi bunting stadium akhir trimester akhir, 13 ekor babi bunting sebagai kontrol dan 13 ekor babi sebagai perlakuan yang disuntik vaksin ETEC multivalen dua kali pada umur kebuntingan 70-75 hari dan booster pada 100-105 hari kehamilan. Induk babi yang divaksin dikelompokkan menjadi 3 yaitu, kelompok A dengan antifimbrial K41, kelompok B dengan antifimbrial 987P, dan kelompok $\mathrm{C}$ dengan Antiimbrial K88. Pengamatan perubahan suhu dilakukan satu hari sebelum vaksinasi sampai 4 hari pasca vaksin dilakukan dengan rancangan acak kelompok. Untuk mengetahui antibodi yang terbentuk, sampel darah diambil seminggu setelah vaksin pertama, dua minggu setelah vaksin pertama, dan lima minggu setelah booster. Sampel darah tersebut kemudian diuji analisisnya menggunakan teknik Enzyme Linked Immunosorbent Assay (ELISA). Tingkat diare dan kematian setelah melahirkan juga diamati. Hasil penelitian diketahui bahwa kadar titer antibodi meningkat secara signifikan pada minggu kelima pada kelompok A dengan titer 1,94 $\pm 0,22$ dan B dengan titer 1,98 $\pm 0,30$, sedangkan angka kejadian diare adalah $0,9 \%$ dibandingkan kontrol $34 \%$ dengan angka kematian $0 \%$. Kesimpulannya, vaksin ETEC multivalen ini aman digunakan dan telah terbukti efektif untuk kasus ETEC pada babi.
\end{abstract}

Keywords: ETEC multivalen, vaksinasi , Booster, Respon antibody, Tingkat kematian

\section{Introduction}

Swine have been raised livestock in Bali Province to meet demands for animal because they have a high economic advantage and social value in Balinese society. Almost all residents, especially in rural areas, raise pigs. The leading cause of disease and death in piglets is Colibaccilosis bacteria (Fairbrother, J. M., 2019) that are responsible for diarrhea, enteritis, bacteremia or septicemia or the combined symptoms. In addition to increasing mortality rate of piglets, incidence increases health care costs and economic losses (Parwati et al, 2019).

On average, breeders in Bali have raised pigs to obtain superior breeds. Each household keeps about 10 sows and potentially produce \pm 10 piglets; therefore, 10 broodstock would 
produce 100 pigs. The piglets are raised for 2-3 months and then they are sold for breeds. The feed is given in the form of a concentrate mixture and fermented coffee husk powder. It could be decreases the incidence of white diarrhea (Colibasilosis) which causes death in pre and post weaning pigs (Parwati et al, 2019).

Pre-weaning mortality is influenced sow milk production, the number of piglets at birth, the uniformity of weight of the piglet, the quality of handling before and after birth, and disease problems. Colibacillosis disease, caused by Enterotoxigenic Eschericia coli or ETEC (Fairbrother et al, 2019), is one of the common causes of piglet mortality in the first two weeks after birth. Colibacillosis is commonly treated with antibiotics, but the result is not encouraging. In fact, ETEC bacteria have shown double resistance (Steffen et al, 2018). The key causes of diarrhea and mortality in neonatal and post-natal piglets are Enterotoxigenic Escherichia coli (ETEC K88, K99, F41 and 987P), accounted for 20-30 percent in the first 2 weeks of each year. Meanwhile, ETEC K99, F41, verotoxigenic Escherichia coli (VTEC) is a trigger of diarrhea and dysentery in dairy calves or beef cattle that causes a large number of deaths (1920 percent) per year (Syarief and Sumoprastowo 1985; Supar et al., 1998). The disease causes financial losses and hinders the growth of the pig population (Hur J, Lee.J, 2013).

Enterotoxigenic Escherichia coli (ETEC) strain causes enterotoxigenic diarrhea characterized by watery diarrhea, dehydration, acidosis, and often causes death (Charter et al., 2004). This stain causes enterotoxigenic colibacillosis in calves, sheep, and pigs (Hur J, Lee J, 2012).

Efforts to control neonatal livestock disease with medication, especially those caused by enterotoxigenic E. coli infection, enteropathogenic using antibiotic preparations are no longer the best method now. Also, the free market has resulted in multiple resistance of ETEC, EPEC, and VTEC isolates to 12-16 types of antibiotics circulating in the field. Therefore, antibiotics are no longer suitable to treat and control colibacillosis (Supar et al., 1990; Supar, 2001). In addition to being ineffective due to the emergence of numerous resistances, antibiotic residues in food products of animal origin and their products often cause potential side effects in connection with contamination. Alternative disease control with vaccine strategies seems a more feasible solution in the future, such as the neonatal control method for colibacillosis vaccines for $\mathrm{E}$. coli K88, K99, F41, or 987P multivalent to produce meat products that are free from contamination and antibiotic residues (Cox E et al., 2014). This study aimed to determine the effectiveness of the Enterotoxigenic Escherichia coli (ETEC) vaccine in gestating sows. The significance of this study is the identification of vaccine effectiveness to reduce the incidence of lethal diarrhea in piglets which causes high economic losses in pig businesses.

\section{Materials and Methods}

This research was conducted in Bukian Village, Payangan District, Gianyar Regency using 26 sows aged 1,5 years and weighed 125 $\mathrm{kg}$ with a body score of 3 (Scale 1 to 3), kept in an individual stall. In a randomized block design, 13 sows were assigned to the control group, and 13 received the vaccine treatment. Sows with the vaccine treatment divided into 3 group that groups A was treated antifimbrial K41, groups B was antifimbrial 987P, while in group $C$ was Antiimbrial K88. The sows were treated using the multivalent Escherichia coli Enterotoxigenic Vaccine (ETEC) produced by the Indonesian Center for Veterinary Research and Development, Bogor, in collaboration with and using the standard operation vaccination from PT Caprifarmindo. This vaccine is injected intramuscularly into the neck area behind the ear at a dose of $2 \mathrm{ml}$ per head every dose in a suspension preparation containing polyvalent $\mathrm{E}$. coli bacteria with a titer of $109 \mathrm{CFU}$. The sows 
were vaccinated (same dose and route) first at 70-75 days of gestation and second (booster) at 100-105 days of gestation. In the next pregnancy (previously vaccinated sows), one vaccine dose was given at 100-105 days gestation. The born piglets must be able to suckle their mother for colostrum, otherwise they suckle other vaccinated sows. Antibodies were determined from blood samples drawn from vena jugularis one week and two weeks after the first vaccine, and one week after the booster (week 5). The blood sample was run in Enzyme-Linked Immunosorbent Assay (ELISA) analysis. The observed variables included the rates of postnatal diarrhea and mortality, the number of piglets with pre-seeding diarrhea, preweaning mortality rate, and the number of weaned piglets. Data were analyzed descriptively and statistically with Anova with an error rate of $1-5 \%$.

\section{Results and Discussion}

\section{Antibodi response}

Fever will occur in the body as a physiological response to vaccine intake. Therefore, changes in body temperature were observed to identify the presence of fever in the sows after receiving multivalent ETEC vaccine. Table 1 shows the body temperature response during the vaccination process to determine the physiological reactions to the multivalent ETEC vaccine.

Table 1 shows that the range of body temperature in the sows is $37.41-37.9{ }^{\circ} \mathrm{C}$, observed from one-day pre-vaccination, during vaccination day, and four-day post-vaccination. The results showed no significant difference in the increased temperature before and after vaccination; therefore, no fever present during this vaccination process with the ETEC vaccine showed no physiological response to this vaccine. Wulandari (2016) reported that clinical examination of the ETEC vaccine showed an increase in body temperature of neonatal calves $24-48 \mathrm{~h}$ after the challenge test to $39.1 \pm$ $0.28^{\circ} \mathrm{C}$ (non-colostrum group) and $39 \pm 0.07^{\circ} \mathrm{C}$ (colostrum group). In our study, the increased body temperature in the colostrum group was within the normal range for neonatal calves, but up to 168 hours after the challenge test, body temperature in the colostrum group gradually decreased to $37.9^{\circ} \mathrm{C} \pm 1.27$.

Table.1. The average body temperature response in the vaccinated sows

\begin{tabular}{lc}
\hline Description & $\begin{array}{c}\text { Average Temperature } \\
\left({ }^{\circ} \mathrm{C}\right)\end{array}$ \\
\hline 1 day prevaccine & $37,48 \pm 0,79$ \\
\hline On vacination day & $37,61 \pm 0,74$ \\
\hline $\begin{array}{l}2 \text { hour post } \\
\text { vaccination }\end{array}$ & $37,9 \pm 0,49$ \\
\hline $\begin{array}{l}4 \text { hour post } \\
\text { vaccination }\end{array}$ & $37,88 \pm 0,50$ \\
\hline $\begin{array}{l}6 \text { hour post } \\
\text { vaccination }\end{array}$ & $37,84 \pm 0,67$ \\
\hline $\begin{array}{l}1 \text { st day post } \\
\text { vaccination }\end{array}$ & $37,88 \pm 0,72$ \\
\hline $\begin{array}{l}2 \text { nd days post } \\
\text { vaccination }\end{array}$ & $37,41 \pm 0,85$ \\
\hline $\begin{array}{l}\text { 3rd days post } \\
\text { vaccination }\end{array}$ & $37,5 \pm 0,73$ \\
\hline $\begin{array}{l}4 \text { th days post } \\
\text { vaccination }\end{array}$ & $37,43 \pm 0,69$ \\
\hline $\begin{array}{l}\text { Source Primary data } \\
\end{array}$ & \\
\hline
\end{tabular}

Source: Primary data

Incorporating antigen through active immunization (vaccination) into the body would allow anti-E-Coli (IgG) antibodies to develop in the blood. We injected the inactivated polyvalent E-coli vaccine (containing enterotoxigenic antigens E-coli K88 and F41 and 987P) to expose the gestating sows to E-coli antigen (via vaccination) in order to generate anti-E-Coli antibodies (IgG). Then, specific antiE-Coli antibodies will be formed by the sows and present in the blood. The sows were vaccinated before calving to increase the production of antibody production in the sows' blood and to improve colostrum quality. An optimum transport of antibodies from mother blood into the colostrum in the udder glands (colostrogenesis) requires the precise timing of vaccination to cows (Hur, 2012). The process of 
colostrogenesis or immunoglobulin transport from the parent blood circulation to the udder glands in ruminants is regulated by hormone, starting from 2-3 weeks before calving and peaks in the last 12 weeks of pregnancy (Hashish, E. A, 2013). This coincides with increased estrogen, decreased progesterone, and increased neonatal receptor ( $F C R n)$ in the udder gland (Hashish, E. A, 2013). The presence of antibodies titers in the sow's blood in response to vaccination can be detected by ELISA testing, which is indirectly expressed in absorbance values (quantity value) which is proportional to the antibody concentration present in the serum. The results of ELISA tests on sow's serum in Table 2 show no significant increase in antibody levels in the first week and the second week among ETEC-vaccinated sows and non-ETEC-vaccinated sows.

The increase in antibody titer was significantly observed in the fifth week after the second injection (booster vaccine) at 100-105 days for sows in groups A (antifimbrial K41) and groups B (antifimbrial 987P), while in group C (Antiimbrial K88) and control pigs did not show a significant difference in the presence of antibody titers. It shows good body response among sows in groups $A$ and $B$, reflected from an increased antibody titer after the second booster. Whereas in group $\mathrm{C}$, the antibody response was not significantly different from that of the control, which is probably due to individual responses and different environments or failed responses because antibodies were not fully formed in the body. Data showed a significant increase in antibodies after the second vaccine, as per previous studies in cattle.

Hur and Lee (2012) reported that E-Coli oral treatment showed significantly increased serum IgG and IgA titers in sows orally primed and boosted with the vaccine compared to the control group. Similarly, colostrum IgA and IgG titer Serum IgA titers were higher than those from the control group. In the control group, the IgG titers serum of piglets at the first week of age remained significant. These results showed that injecting gestating sows with the candidate vaccine may provide immunity for the piglets up to the weaning stage. The vaccine candidates were further examined for safety and protection against ETEC infection. Side effects such as diarrhea, abortion, and abnormal behavior were not present in any immunized gestating sows from day 1 postimmunization until day 28 after farrowing (Hur and Lee, 2012). Data ELISA analysis of multivalent antigen within ETEC multivalent is present in Table 3.

Table 2. The titer antibodies descripton in blood serum per week after ETEC multivalent vaccination on three groups of Sows compare to controls group

\begin{tabular}{ccccc}
\hline Description & Group A & Group B & Group C & Control \\
\hline Week 1 & $1,76 \pm 0,21^{\mathrm{a}}$ & $1,63 \pm 0,31^{\mathrm{a}}$ & $1,48 \pm 0,24^{\mathrm{a}}$ & $1,39 \pm 0,30^{\mathrm{a}}$ \\
Week 2 & $1,84 \pm 0,20^{\mathrm{a}}$ & $1,72 \pm 0,32^{\mathrm{a}}$ & $1,71 \pm 0,23^{\mathrm{a}}$ & $1,34 \pm 0,30^{\mathrm{a}}$ \\
Week 5 & $1,94 \pm 0,22^{\mathrm{b}}$ & $1,98 \pm 0,30^{\mathrm{b}}$ & $1,60 \pm 0,22^{\mathrm{a}}$ & $1,67 \pm 0,29^{\mathrm{a}}$ \\
\hline
\end{tabular}

Note: Different superscript on the same row showed significantly different $\mathrm{P}<0.05$

Table 3. Antibody respon to each type of antigen containing in Multivalent ETEC vaccine (Antigen K41, Antigen 987P and Antigen K88)

\begin{tabular}{clccc}
\hline No & Antigen & Week 1 & Week 2 & Week 3 \\
\hline 1 & Antifimbial K41 & $1,75 \pm 0,20^{\text {a }}$ & $1,84 \pm 0,47^{\text {a }}$ & $1,94 \pm 0,32^{\text {a }}$ \\
2 & Antifimbrial 987P & $1,63 \pm 0,45^{\text {a }}$ & $1,72 \pm 0,46^{\mathrm{a}}$ & $1,97 \pm 0,30^{\text {a }}$ \\
3 & Antifimbrial K88 & $1,48 \pm 0,24^{\text {a }}$ & $1,71 \pm 0,56^{\text {a }}$ & $1,60 \pm 0,48^{\text {a }}$ \\
\hline
\end{tabular}

Source: Primary data analysis 
Data in Table 3 showed an optical density response to multivalent ETEC vaccination from the first week, the second week, to the fifth week (one week after booster). Response to inactivated polyvalent $E$-coli vaccine (containing enterotoxigenic antigens E-coli K88, F41 and 987P) triggered the development of anti E. Coli (IgG) antibodies in the blood. However, there were no significant differences across the three antigens responses in the sows. It means that all antigen responds similarly to induce antibodies (IgG), hence, no specific antigen gave more significant responses than other antigens. The increase in antibody titer was not significant between groups $C$ and the control due to a lack of time to observe the increase in antibody titers. Previous research introduced E. coli antigen to determine the presence of antiE. coli antibodies in the blood of cows. Our study showed that anti E. coli was remained undetected in the blood sample before the first vaccination, two weeks after the first vaccination, and up to 2 weeks after the second vaccination. If antibodies contained in the serum sample were few or zero, then less conjugation was bound, resulting in less substrate reaction, the color appeared weak, and the OD value declined (Hur and Lee, 2012). In the indirect ELISA, the OD value will be proportional to the antibody concentration. Anti-E. coli antibodies can only be detected in the serum of vaccinated cows four weeks after the second vaccination.

\section{Postnatal Diarrhea and Mortality Rate}

Based on that result in Table 4. The average number of piglets born from vaccinated and non-vaccinated sows was 11,38 and 11 heads, respectively. The total piglets with signs of diarrhea were 12 or $0,9 \%$ with a mortality rate was $0 \%$, while the non-vaccinated was about 48,62 heads (34\%) with a mortality rate of about 35,8 heads or $25 \%$. With vaccination, all piglets (148 heads) were weaned, but without vaccination, only 107,25 (75\%) were weaned. Utami and Parwati (2014) reported that the Multivalen ETEC vaccine could reduce the incidence of diarrhea by $75.5 \%$ (from $88 \%$ to $12.5 \%)$ and reduce the pre-weaning mortality rate by $24.33 \%$ (from $27 \%$ to $2.67 \%$ ), so the total average of weaning pigs increased from $73 \%$ to $97.33 \%$. In our study, the total weaned pigs increased from $77.56 \%$ to $95.25 \%$ and $2.4 \%$ to $4.7 \%$. In addition to pre-weaning mortality, vaccination will decrease the occurrence of ETEC diarrhea from $35.2 \%$ to $6.04 \%$, and from $35.29 \%$ to $19.81 \%$, thereby raising the total piglets that can be weaned from $44.11 \%$ to $80.19 \%$. The previous studies reported that preweaning mortality was only $0.68 \%$ (Utami and Parwati, 2014). Rai et al. (2001) show that ETEC vaccination titer antibodies Ig $G$ and Ig $A$ from vaccinated sows are significantly higher $(P<0.01)$ than non-vaccinated sows whose antibodies decreased by the first milk (Colostrums), so piglets born from vaccinated sows are resistant to $\mathrm{E}$. coli infection.

To control neonatal diarrheal disease caused by ETEC, early treatment of this disease is very important. One form of control is the provision of passive immunization to calves through cows' colostrum. This can be realized when ETEC contains antibodies specific to the virulence factors. Accordingly, the multivalent ETEC vaccine can prevent economic losses in raising pigs.

Table 4. The Presentage data piglet born with diarhea, mortality, weaning Number

\begin{tabular}{lccccccc}
\hline \multirow{2}{*}{ Treatment } & The average & \multicolumn{2}{c}{ Diarhea } & \multicolumn{2}{c}{ Preweaned mortality } & \multicolumn{2}{c}{ Weaning number } \\
\cline { 2 - 8 } & piglets birth & Head & $\%$ & Head & $\%$ & Head & $\%$ \\
\hline Without vaccination & 11 & 48,62 & 34 & 35,8 & 25 & 107,25 & 75 \\
Vaccination & 11,38 & 12 & 0,9 & 0 & 0 & 148 & 100 \\
\hline
\end{tabular}

Source: primary data 


\section{Conclusions}

ETEC vaccine to swine does not give physiological reactions like fever at sows it is safe with a small level of risk. The incidence of post-vaccine diarrhea is still present but the incidence rate is small (0.9\%) and $100 \%$ of the piglets reach weaning age safely. Antibody titer significantly increased in the fifth week or one week after the booster. Multivalent ETEC vaccine containing E coli K88 and F41 and 987P antigens is effective to prevent Colibaccilosis cases in newborn piglets.

\section{References}

Chotiah, S. 2013. Strategic control of acute diarrhea of newborn calves. Journal of Animal and Veterinary Science, 17 (3).

Cox, E, V Melkebeek, B Devriendt, B Goddeeris, and D Vanrompay. 2014. Vaccines against enteric $E$. coli infections in animals. Pathogenic Escherichia Coli: Molecular and Cellular Microbiology, 255270.

Fairbrother, JM, and É Nadeau. 2019. Colibacillosis. Diseases of swine, 807-834.

Hashish, EA, C Zhang, X Ruan, DE Knudsen, CC Chase, RE Isaacson, ... and W Zhang. 2013. A multiepitope fusion antigen elicits neutralizing antibodies against enterotoxigenic Escherichia coli and homologous bovine viral diarrhea virus in vitro. Clinical and Vaccine Immunology, 20(7), 1076-1083.

Hur, J, and JH Lee. 2012. Comparative evaluation of a vaccine candidate expressing enterotoxigenic Escherichia coli (ETEC) adhesins for colibacillosis with a commercial vaccine using a pig model. Vaccine, 30(26), 3829-3833.

Hur, J, and JH Lee. 2012. Development of a novel live vaccine delivering enterotoxigenic Escherichia coli fimbrial antigens to prevent post-weaning diarrhea in piglets. Veterinary immunology and immunopathology, 146(3-4), 283-288.

Hur, J, and JH Lee. 2013. Protection against neonatal Escherichia coli diarrhea by vaccination of sows with a novel multivalent vaccine candidate expressing E. coli adhesins associated with neonatal pig colibacillosis. Research in Veterinary Science, 94(2), 198-204. https://doi.org/10.1016/j.rvsc.2012.08.004

Melkebeek, V, BM Goddeeris, and E Cox. 2013. ETEC vaccination in pigs. Veterinary immunology and immunopathology, 152(1-2), 37-42.

Nagy, LK, T MacKenzie, KR Painter. Protection of the nursing pig against experimentally induced enteric colibacillosis by vaccination of dam with fimbrial antigens of $E$ coli (K88, K99 and 987P). Vet Rec. 1985;117(16):408-413. doi:10.1136/vr.117.16.408

Parwati, IA, N Suyasa, and ASJ Utami. 2019. Level Of Swine Productivity On The Swine Development Program In Gianyar Region. In Proceeding of the International Conference on Food and Agriculture (Vol. 2, No. 1).

Priyadi, A, and L Natalia. 2005. Bakteri Penyebab Diare pada Sapi dan Kerbau di Indonesia. Seminar Nasional Teknologi Peternakan dan Veteriner 2005. http://peternakan.litbang.deptan.go.id Download:16 Juli 2009

Supar, RG Hirst, and BE Patten. 1990. Antimicrobial drug resistance in enterotoxigenic Escherichia coli K88, K99, F41, and 987P isolated from piglets in Indonesia. Penyakit Hewan 22: 13-19.

Supar. 1996. Studi Kolibasilosis Pada Anak Sapi Perah dan Deteksi Escherichia coli K99, F 41 dan K99F41 dalam Prosiding Temu Ilmiah Nasional Bidang Veteriner. Maret 1996. p148-155

Steffen, R, ZD Jiang, ML Gracias Garcia, P Araujo, M Stiess, T Nacak, ... and HL DuPont. 2018. Rifamycin SV-MMX ${ }^{\circledR}$ for treatment of travellers' diarrhea: equally effective as ciprofloxacin and not associated with the acquisition of multi-drug resistant bacteria.

Takeyama, N, Y Yuki, D Tokuhara, K Oroku, M Mejima, S Kurokawa, ... and H Kiyono. 2015. Oral rice-based vaccine induces passive and active immunity against enterotoxigenic $E$. colimediated diarrhea in pigs. Vaccine, 33(39), 52045211.

Yasa, R, YA Parwati, S Guntoro, N Suyasa, and IK Saka. 2000. The effect of enzyme on pig fattening. In Prosiding seminar pengembangan teknologi pertanian ramah lingkungan, Denpasar (Indonesia), 8-9 Mar 2000. Pusat Penelitian Sosial Ekonomi.

Yasa, RIM, and IA Parvati. 2001. Disease Control kolibasilosis with multivalent ETEC vaccine. Papers of the National Seminar on Economic Cooperation Center for Agricultural-Bogor Institute for Agricultural Technology-Bali.

Wulansari, R, A Esfandiari, IWT Wibawan, and S Murtini. 2016. Kinerja Kesehatan Sapi Neonatus yang Diberi Kolostrum dari Induk Sapi yang Divaksin Escherichia coli. Acta VETERINARIA Indonesiana, 4(1), 19-26. 